\title{
New insights in the diagnosis of placenta accreta
}

\author{
Capros Hristiana, Luminita Mihalcean, Iurie Dondiuc, Liliana Porfire
}

Department of Obstetrics and Gynecology, Nicolae Testemitsanu State University of Medicine and Pharmacy, Chisinau, Moldova.
This work is licensed under a

Creative Commons Attribution 4.0 International License

Received: 29-11-2017

Accepted: 22-12-2017

UDC: 616.6

\section{J Clin Med Kaz 2017;4(46):40-45}

Correspondence address: Capros Hristiana, M.D., $\mathrm{PhD}$. Department of Obstetrics and Gynecology, Nicolae Testemitsanu State University of Medicine and Pharmacy, Stefan cel Mare si Sfant Boulevard 165, Chisinau 2004, Moldova. GSM: +373 060544661, E-mail: caproscristina@yahoo.com

\section{Abstract}

In this case report we present a patient of 39 weeks pregnancy with a placenta accreta and discuss the new possilities of diagnosis of placental masses with respect to the related literature. The aim of our review was to assess the available useful procedures in an attempt to contribute to the decreasing the morbidity of this condition.

Twenty-nine years-old gravida 2, para 0 was referred to our hospital at 38 weeks of gestation for planed delivery by cesarien section. She had a history of prior surgical pregnancy termination at 12 weeks of amenorrhea by dilation and curettage. The abnormal placentation was diagnosed during a routine sonographic examination at 22 weeks of gestation. 2D transvaginal ultrasound showed the total placenta praevia and the presence of multiple intraplacental lacunae. The placenta did not detach with gentle traction, so placenta accreta was suspected. Heavy bleeding hemorrage from the placental site induced the decision to perform an emergency hysterectomy.

The prenatal diagnosis of placenta accreta before delivery allows multidisciplinary planning and minimize potential maternal or neonatal morbidity and mortality. Grayscale ultrasonography with the use of color Doppler is sufficient to diagnose placenta accreta. The knowlege of the ultrasound markers for placenta accreta is needed for both radiologist and obstetricians-gynecologist.

Keywords: Placenta accreta, placentar lacunae, turbulent blood flow.

\section{ЖАБЫСЫП ӨСКЕН ЖОЛДАСТЫ ДИАГНОСТИКАЛАУДЫҢ ЖАНА ИДЕЯЛАРЫ}

Capros Hristiana, Luminita Mihalcean, Iurie Dondiuc, Liliana Porfire

Акушерлік және гинекология кафедрасы, Николай Тестемицану атындағы Мемлекеттік медицина және фармация университеті, Кишинев, Молдова.

\section{ТҰЖЫРЫМДАМА}

Біз жолдас патологиясымен жүктілік клиникалық жағдайын ұсынамыз және ұрықжолдастылар массасын диагностикалаудың жаңа мүмкіндіктерін талқылаймыз. Біздің шолуымыздың мақсаты заманауи әдебиетте сипатталған қолжетімді пайдалы ұсынымдарды талқылау болып табылды. Жиырма тоғыз жастағы жүкті әйел, гравида 2, 0 жұбы біздің ауруханаға жоспарлы операция үшін 38 апта жүктілігі мерзімінде жіберілді. Оның бұрындары қырып тазарту жолымен етеккірсіздіктің 12 аптасында жүктілігін хирургиялық тоқтату болған. Жалпы нормадан ауытқыған плацентация 22 жүктілік аптасында сонографиялық тексеру кезінде диагностикаланды. 2D трансвагинальді Удт рlacenta praevia және көптеген ұрықжолдастылар ішіндегі лакунанын барын көрсетті. Жаңа туған жолдасты шығарғаннан кейін ажырамады, сондықтан аккрет жолдасы сезіктенді. Бала жолдасынан қанның көп кетуі жедел жатырды алып тастауды орындау үшін көрсеткіш болды.

Босануға рұқсат алдында placenta accreta туу алды диагностикалау көп тәртіптік жоспарлау өткізуге және аналардың немесе жаңа туған нәрестелердің әлеуетті аурушаңдығы мен өлімін азайтуға мүмкіндік береді. Түрлі-түсті допплерді пайдаланумен Graу sсаlе ультраснографиялау жолдастың акцентін диагностикалауға жеткілікті. placenta accreta үшін ультрадыбыстық маркерлерді радиолог-дәрігерлерге де, сондай-ақ акушер-гинекологтарға да білу қажет.

Түйінді сөздер: жолдастың, лакуна жолдастың жетілуі, турбулент қанағым. 


\section{PEЗЮME}

Мы представляем клиничиский случай беременности с патологией плаценты и обсуждаем новые возможности диагностики плацентарных масс. Цель нашего обзора состояла в том чтобы обсудить доступные полезные рекомендации описанные в современной литературе.

Двадцать девятилетняя беременная, гравида 2, пара 0 была направлена в нашу больницу на 38 неделе беременности для плановой операции. У нее была история предшествующего хирургического прерывания беременности на 12 неделе аменореи путем выскабливания. Аномальная плацентация была диагностирована во время обычного сонографического обследования на 22 неделе беременности. 2D трансвагинальное УЗИ показало placenta praevia и наличие множественных внутриплацентарных лакун. После извлечения новорожденного плацента не отсоединялась, поэтому подозревалась плацента аккрета. Массивное кровотечение из плацентарного участка послужило показанием для выполнения экстренной гистерэктомии.

Пренатальная диагностика placenta accreta перед родоразрешением позволяет проводить многодисциплинарное планирование и минимизировать потенциальную заболеваемость и смертность матерей или новорожденных. Ультрасонографии в Gray sсаlе с использованием цветного допплера достаточно для диагностики акценты плаценты. Знание ультразвуковых маркеров для рlacenta ассreta необходимо как для врачей радиологов, так и для акушеров-гинекологов.

Ключевые слова: приращение плаценты, лакуны плаценты, турбулентный кровоток.

\section{Introduction}

Placenta accreta is a major public health problem due to complications that have a direct impact on the most important reproductive health indicators: maternal morbidity and mortality, perinatal morbidity and mortality. The incidence of placenta accreta is around 3 per 1000 deliveries, with a considerable increase over the past years. In most studies, the reported morbidity rate in placenta accreta is $7-10 \%$, but there are obstetrics units reporting a rate as high as $29 \%[1,2]$. Placenta accreta is one of the most common causes of postpartum hysterectomy, more than $50 \%$ of women with placenta accreta are transfused, $40 \%$ of them receive 10-12 units of freshly frozen plasma [3]. At present, there is little data that could serve as a solid foundation for optimal management of placenta acreta, accreta and percreta. Existing literature consists predominantly of clinical case-control reports or retrospective studies conducted in single hospitals or in a small number of third level medical institutions using medical records over a limited number of years. No randomized controlled trials were published. These studies have a number of limitations, including limited generality and a lack of serious statistics. In this case report we present a patient of 39 weeks pregnancy with a placenta accreta and discuss the new possilities of diagnosis of placental masses with respect to the related literature. The aim of our review was to assess the available useful procedures in an attempt to contribute to the decreasing the morbidity of this condition.

\section{Case Presentation}

Twenty-nine years-old gravida 2, para 0 was referred to our hospital at 38 weeks of gestation for planed delivery by cesarien section. She had a history of prior surgical pregnancy termination at 12 weeks of amenorrhea by dilation and curettage.

The abnormal placentation was diagnosed during a routine sonographic examination at 22 weeks of gestation. Transvaginal gray-scale exam suggested the diagnosis of placenta previa. 2D transabdominal ultrasound showed the total placenta praevia and the presence of multiple intraplacental lacunae. The diagnosis of placenta accreta was not suspected at that time. The thinkness of uterine wall was not measured, and no color Doppler examination was performed.

On admission, an abdominal ultrasound examination showed a viable fetus with appropriate biometrical parameters and normal amniotic fluid. On the scheduled day of delivery, a abdominal opening by Phannenstiel access was performed.
After opening the abdominal wall, intra-abdominal inspection showed the presence of multiple large vessels at level of the lower uterine segment. An initial displacement of the bladder was performed and subsequently a transverse uterine incision was made above the lower uterine segment in order to avoid placental bed. A healthy neonate weighing $2980 \mathrm{~g}$ was delivered.

The placenta did not detach with gentle traction, so placenta accreta was suspected. As spontaneous placental extraction failed, the placental tissue was manually removed, and the placental site was inspected by instrumental review. Heavy bleeding hemorrage from the placental site induced the decision to perform a hysterectomy. The uterine incision was quickly sutured closed using a single running layer with a large suture to decrease bleeding prior to starting the hysterectomy. The round ligament is identified, clamped divided, suture ligated, and suspended for traction. The broad ligament was opened its anterior leaf opened medially towards the bladder flap, which separates the bladder peritoneum from the lower segment of the uterus. The uteroovarian ligaments were clamped, and divided bilaterally. The uterine arteries isolated and ligated. The uterus was remouved and the abdomen was closed using a regular technique. The total blood loss was $2000 \mathrm{ml}$. Intraoperative evaluation boold count revealed a hemoglobin of $72 \mathrm{~g} / \mathrm{ml}$. Intraoperative allogeneic red blood cells and free-frozen plasma were transfused. The patient was cared for in the intensive care for one day. The postoperative course was uneventful, and the patient was discharged on day 7 in good conditions. Histopathological examination confirmed placenta accreta.

\section{Discussion}

The optimal management of placenta accreta remains a topic of debate, but, generally, in the case of suspected placenta acreta, premature planed cesarien delivery with hysterectomy is recommended [4]. Royal College of Obstetricians and Gynaecologists recommends, if placenta fails to separate after delivery, to leave it in place and to proceed with a hysterectomy or conservative management. So, the placenta is not detached but left in situ, because extraction of the placenta is associated with significant haemorrhage morbidity [5].

All the obstetricians and interventional radiologists should be familiar with the risk factors and modalities of diagnosis for placenta acreta due to its potential risk of an emergency situation in obstetrics that puts women's life in danger through massive hemorrhage. If there is a suspicion of abnormal 
placental invasion, managers of small hospitals or institutions with insufficient blood supply or inappropriate staff availability should consider transferring the patient to a tertiary perinatal care center. Better results have been demonstrated when these patients are delivered in specialized level III centers [6]. The posibility to manage the massive transfusions and the availability of other technical skills (urologists, vascular surgeons) is essencial. It is logical that expertise and professional experience are useful when managing difficult and somewhat uncommon problems.

Most placenta accreta are asymptomatic during pregnancy. This is why in a lot of cases diagnosis of placenta accreta, increta and percreta is clinical. After the delivery of the neonate, placenta does not separate spontaneously, and cannot be removed without causing abnormal usually masive obstetrical bleeding [7]. The final diagnosis of placenta accreta is histopathological, that means obtained after hysterectomy. On the histological specimen the absence of the decidual layer will be noticed, so the chorionic villi embedded in the myometrium [8]. The diagnosis of placenta accreta can be also suggested by ultrasound examination.

Patients at risk of placenta accreta should be identified during pregnancy. Prenatal diagnosis of placenta accreta, diminished the transfusion of freshly frozen plasma and cryoprecipitate. It was found that in the patients in whom the diagnosis was established antenatally, the delivery was completed more frequently by planed cesarean surgery [9]. Maternal morbidity is reduced in women with placenta accreta diagnosed antenatally. The antenatal diagnosis has been associated with a lower number of hemorrhages and fewer haematransfusions. This decrease in maternal morbidity for patients with prenatal placental accreta was also reported in other studies $[10,11]$. Another advantage

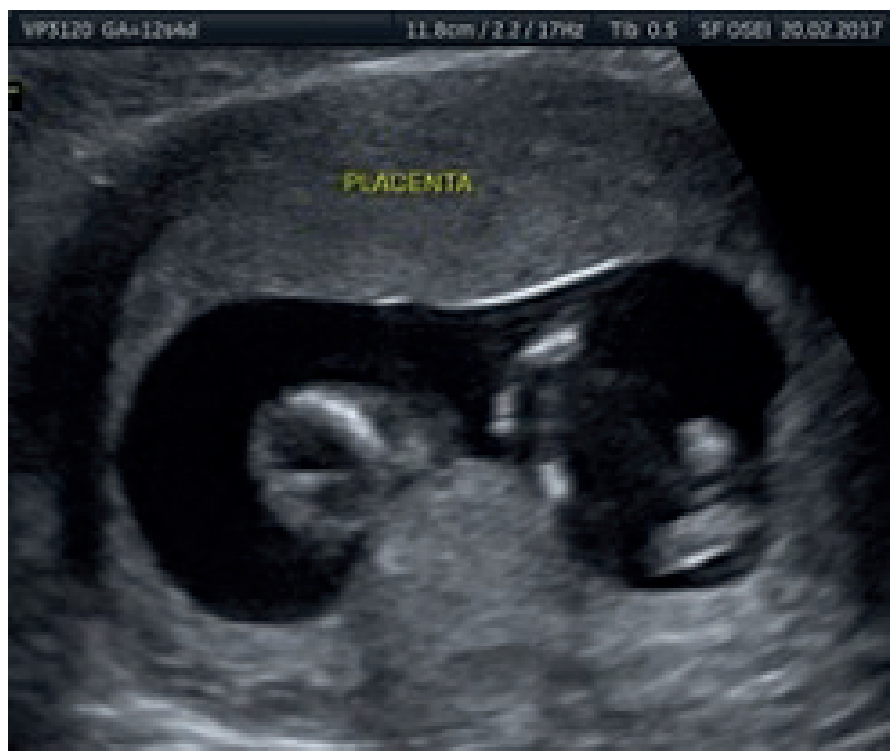

of prenatal identification is the possibility to schedule the delivery in a specialized center with a multidisciplinary team and appropriate equipment and resources, including an intensive care unit, an interventional radiology embolization unit, a blood bank capable to manage a massive hemorrhage [12].

In this way the prenatal diagnosis of placenta accreta allows:

to make an early delivery planning,

to assess the right delivery time,

to minimize the hemorrhagic risk,

to reduce the surgical complications,

to reduce the hospitalizations in reanimations units,

to decrease the maternal morbidity and mortality [13].

Placenta accreta represents a form of pathological placentation characterized by the placental villi being abnormally adherent to the myometrium because of the total or partial absence of Nitabuch membrane. This membrane has a crucial role in the placenta detachement during the third stage of labor $[14,15]$.

Ultrasound diagnosis of placenta accreta.

The ultrasound examination should be the first-intention investigation and, in most cases, sufcient examination for the diagnosis of placenta accreta [16].

In order to detect the pathological changes, it is necessary to know how a normal placenta is presenting on ultrasound.

Normal placental ultrasound:

The normal placenta is presentiting like a focal mass, with granular structure. In the first and second trimester, the normal placenta has homogeneous ecogeneity, with some thin septa, surrounded by hypoecoic myometrium (Figure 1,2).

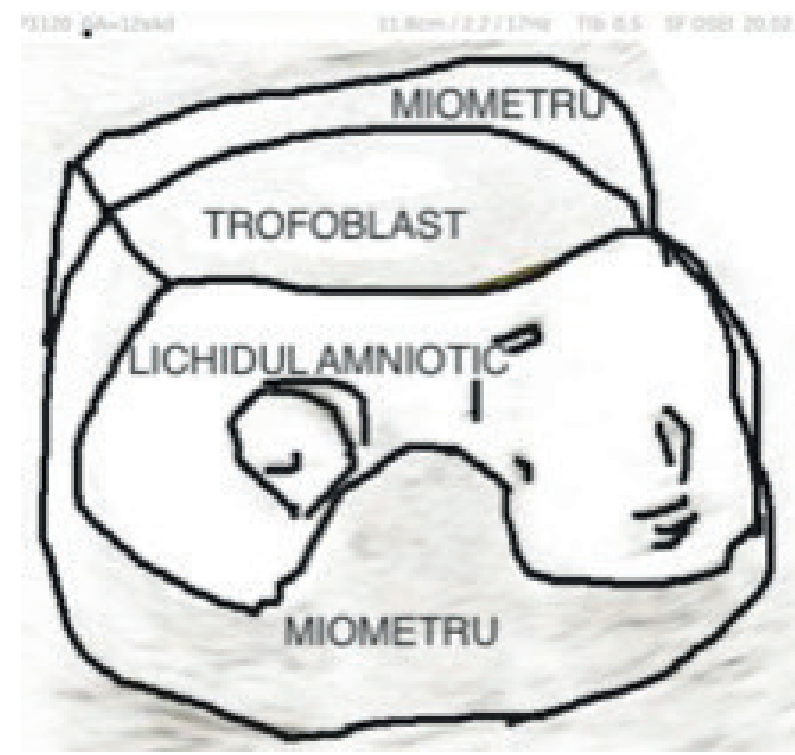

Figure 1 - Transabdominal ultrasound showing the anterior placenta in the first trimester of pregnancy exhibiting the following ultrasonographic signs of normal placenta : inserted in the fundus of uterus, thick retroplacentar myometrium, placenta homogenious, no placental lacunae, no placental bands.

Placenta is inserted in the fundal part of the uterus. The retroplacental area has a regular appearance and is translucent. Already at 5-6 weeks' gestation, the trophoblastic tissue surrounding the gestational sac appears as an echogenic ring, with an unchanging thickness around the entire sac. The trofoblast, which will develop into the placenta, and the cord insertion site can be seen clearly from 7-8weeks, as can the spiral arteries that have opened in response to implantation. 7-9 weeks of gestation will allow identification of those pregnancies with complete implantation in the uterine istmus [17]. 

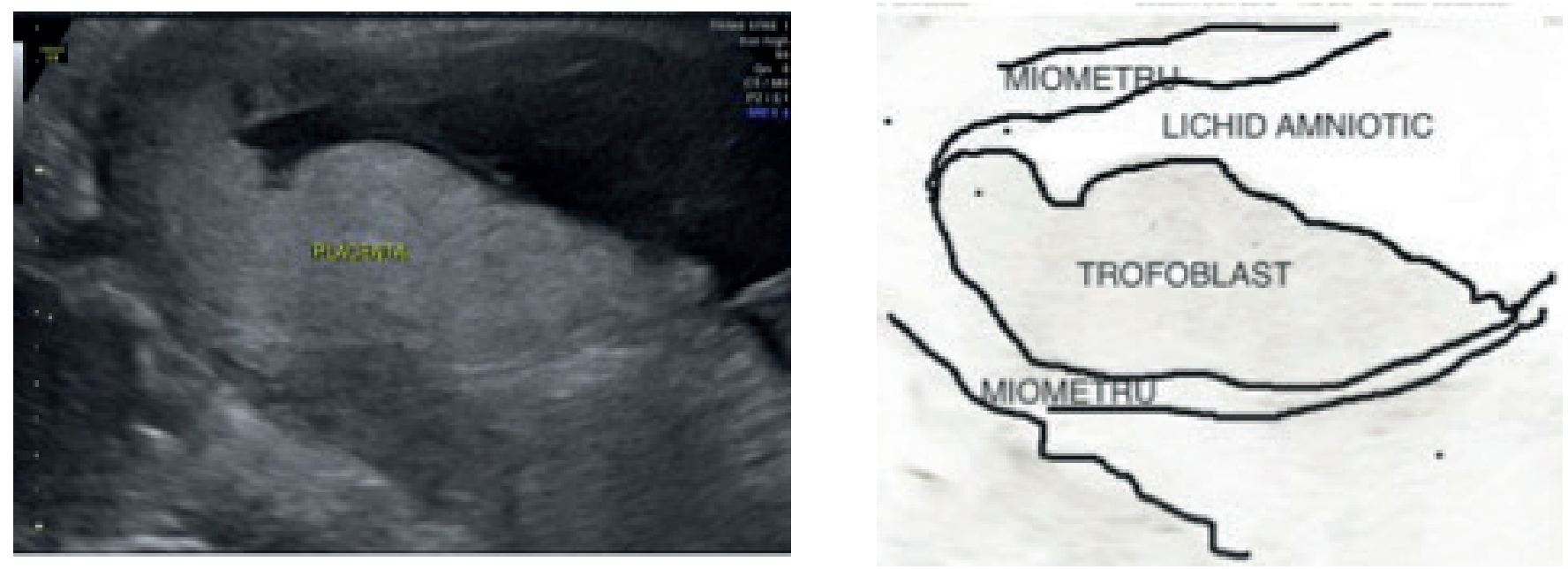

Figure 2 - Transabdominal ultrasound showing normal placenta in the second trimester of pregnancy: granular homogenious echostructure of placenta is well- demarcated from the adjacent miometrium.

In color Doppler exploration, blood flow distribution is parallel to the retroplacental line. In the third trimester of

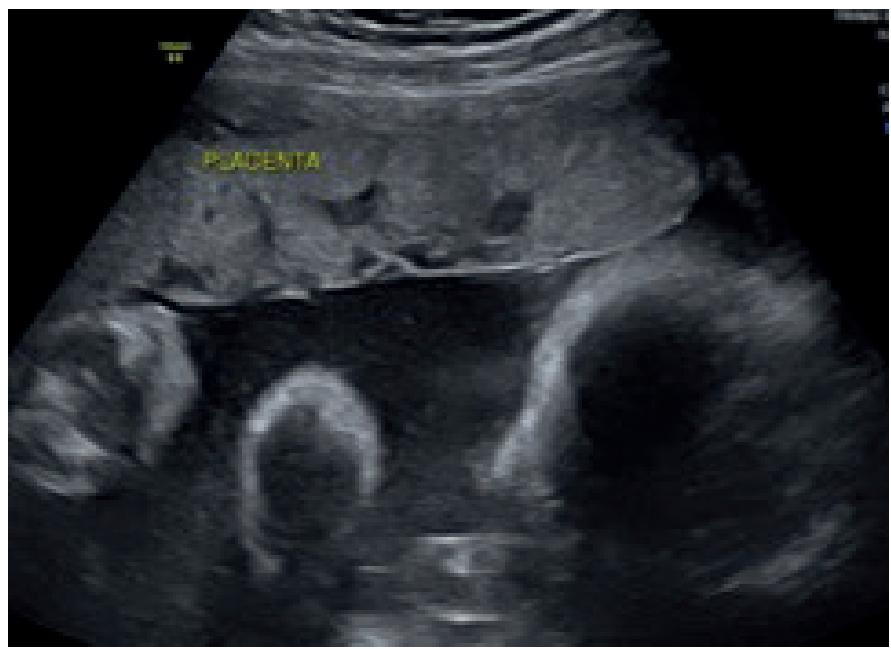

pregnancy, venous lashes and calcifiers appear, giving to the placenta a heterogeneous appearance (Figure 3) [18].

Figure 3 - Anterior placenta in the third trimester of pregnancy: hyperechoic placenta is surrounded by the hypoechoic myometrium, some calsifications and vascular lacs are seen.

Thus, in the first, second and third trimester of pregnancy, we will examine:

- Placental location

- the appearance and homogeneity of the placenta

- the interface between the bladder and the serous uterus

- the thickness of the retroplacental myometrium

I. Diagnosis of placental accreta is possible from the first trimester of pregnancy.

Several cases of massive haemorrhage in the first trimester of pregnancy have been reported following dilation and curettage due to incomplete detachement of chorion residues. The morphopathological examination of the placenta and extracted uterus has been shown placenta to be invasive or adherent and the absence of the deciduous membrane between the myometrium and the placenta. It is reasonable to assume that abnormal placentation was present at the time of implantation $[19,21]$.

In the series described, the most frequently reported risk factor was scares tissue, although some cases were reported in women with no prior surgery [20, 24].

The specific echographic signs for placenta accreta can be used very early in pregnancy, in the - 4-5 weeks of amenorrhea.

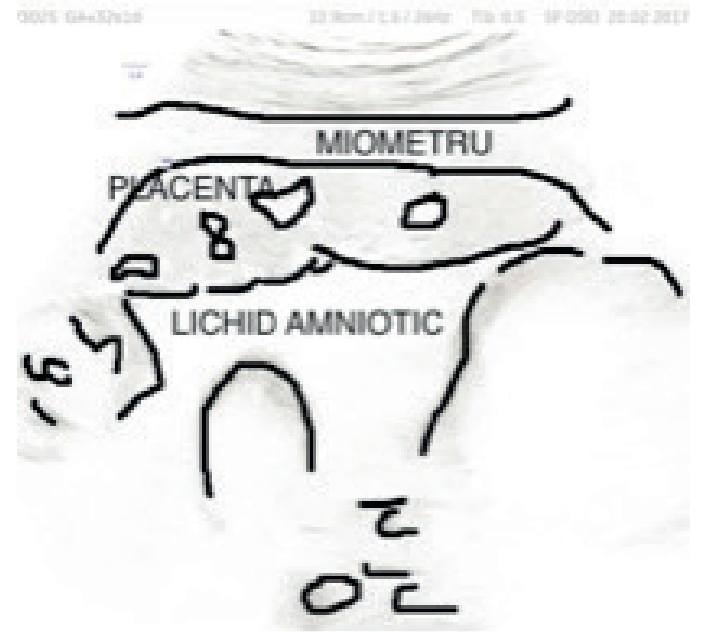

Specialty literature describes several markers that would be prognostic for the development of placenta accreta. These ultrasounds markers are:

1. Implantation of the gestational sac in the lower segment of the uterus.

Normally, the fetal egg will be implanted in the fundus of the uterus. Comstoc et al. in a series of cases of histologically confirmed placenta accreta retrospectively analyzed ultrasound images taked in the first trimester of pregnancy. Available pictures showed the gestational sac implanted in the uterin istmus [22]. This implantation in the lower uterine segment in adhering morbid placenta must be differentiated from cervical pregnancy, stagnant pregnancy, imminence of spontaneous abortion. Terminology in the literature is confusing, occasionally low implantation of the fetal egg is called a cervico-ismical task, although this term implies an increase in placenta in the cervix. Symptomatic catalysis bleeding such as ischemic-cervical pregnancy and pregnancy implanted in caesarean cervix made these two nosologies included in similar groups in the published studies. Surapanani et al. Have investigated cesareusalpingografia cesarean post-operative scars and diagnosed linear defects in 60 percent of invested patients [23]. 
Unlike cervico-ismical pregnancy and pregnancy with placenta accreta, sarcasm in cesarean scar is the implantation of the fetal egg in this muscle defect.

In the stagnated pregnancy and the imminence of spontaneous abortion will lack the blood flow around the implanted egg [25].

2. The presence of multiple irregular vascular spaces observed in the placental bed;

3. Implantation of the gestational sac on the scar from the caesarean section, either at the internal opening of the cervical canal or at the base of the bladder.

At present only series of cases or isolated cases of placental diagnosis are published in the first trimester of pregnancy, for which reason the sensitivity, specificity, predictive and negative value of this marker remains to be determined. Clearly, however, pregnant women with the gestational sac lowered in the first trimester of pregnancy should be closely monitored ultrasonographically until the third trimester of pregnancy [26].

Alternatively, the current recommendations in case of finding gestational sac in the scar include the injection of methotrexate directly into the gestational sac due to the major risk of developing placenta percreta [27].

Regardless of the imaging modalities, the diagnosis of placenta accreta is subjective, and depends greatly on the operator's knowledge and experience. For some time, the ultrasound scan was based on gray scale and typical signs such as «placental gaps» and «loss of transplanted retroplacental area,» «placental turbulent flow»[28]. There is no consensus in the definition of ecograff markers. Different signs were described under different names, and in other cases, the same term was used for different findings. With the development of ultrasound techniques, and the possibility of obtaining detailed quality images, ultrasonographic markers for the diagnosis of adherent morbid placenta have been reviewed. Several studies have evaluated the predictive value of these echographic markers. The European Abnormally Invasive Placenta Working Group to enhance diagnostic capabilities and facilitate international collaboration, proposes to use standardized definitions of markers in placenta accreta.

The ecographic markers for the placenta accreta are.

1. Placenta previa

2. Placental lacunae

3. Turbulent placental flow

4. Loss of the retroplacental clear space

5. Reduced myometrial thickness [29, 30].

The American College of Obstetricians and Gynecologists for transvaginal ultrasound with gray scale cites the sensitivity between 77 to $87 \%$, the $96-98 \%$ specificity, the predictive negative value $65-93 \%$, and the predictive positive value $98 \%$ (Table 1) [3].

Table 1 Ultrasound in the diagnosis of placenta accreta [31]

\begin{tabular}{|l|l|l|l|l|l|}
\hline & N. of patients & Sensitivity & Specificity & $\begin{array}{l}\text { Positive predictive } \\
\text { value }\end{array}$ & $\begin{array}{l}\text { Negative predictive } \\
\text { value }\end{array}$ \\
\hline Esakoff et al. & 108 & 89 & 91 & 68 & 98 \\
\hline Shih et al. & 170 & 97 & 92 & 77 & 99 \\
\hline Warshak et al. & 453 & 77 & 96 & 65 & 98 \\
\hline Dwyer et al. & 32 & 93 & 71 & 74 & 92 \\
\hline Wong et al. & 66 & 89 & 98 & 89 & 98 \\
\hline Chou et al. & 80 & 82 & 96 & 87 & 95 \\
\hline Lim et al. & 13 & 67 & 50 & 75 & 40 \\
\hline
\end{tabular}

\section{Conclusions}

Placenta accreta is an ever-feared obstetric complication charectirized by a pathological invasion of placental tissue into the myometrium of the uterus. The forcible removal of the placenta can lead to massive obstetical hemorrhage. Two main risc factors for placenta accreta are placenta previa and previous uteine surgery. The prenatal diagnosis of placenta accreta before delivery allows multidisciplinary planning and minimize potential maternal or neonatal morbidity and mortality. Grayscale ultrasonography with the use of color Doppler is sufficient to diagnose placenta accreta. The knowlege of the ultrasound markers for placenta is needed for both radiologist and obstetricians-gynecologist.

\section{Reference}

1. Abuhamad A, Abuhamad. Morbidly adherent placenta. Seminars in perinatology. 2013;37(5):359-64.

2. Al-Khan A, Gupta V, Illsley NP, et al. Maternal and fetal outcomes in placenta accreta after institution of team-managed care. Reprod Sci 2014; 21: 761-771.

3. American College of Obstetricians and Gynecologists. ACOG Committee Opinion. Placenta accreta. Washington, DC: ACOG, 2015.

4. American College of Obstetricians and Gynecologists. Postpartum hemorrhage. ACOG DC: ACOG; 1998.

5. Royal College of Obstetricians and Gynaecologists. Placenta Praevia, Placenta Praevia Accreta and Vasa Praevia: Diagnosis and Management- Green-top Guideline No. 272011. Available from:http://gynerisq.fr/wp-content/uploads/2013/12/2011-RCOGplacenta praevia_accreta_vasa-praevia.pdf.

6. Amsalem H, Kingdom JC, Farine D, Allen L, Yinon Y, D’Souza DL, et al. Planned caesarean hysterectomy versus “conserving” caesarean section in patients with placenta accreta. Journal of Obstetrics and Gynaecology Canada 2011; 33(10):1005-10. 
7. Balayla J, Bondarenko HD. Placenta accreta and the risk of adverse maternal and neonatal outcomes. J Perinat Med 2013; 41: $141-149$.

8. Bowman ZS, Eller AG, Bardsley TR, Greene T, Varner MW, Silver RM. Risk factors for placenta accreta: a large prospective cohort. American Journal of Perinatology 2014; 31(9):799-804.

9. Robinson B, Robinson W, Grobman. Effectiveness of Timing Strategies for Delivery of Individuals With Placenta Previa and Accreta. Obstetrical \& gynecological survey. 2011;66(1):4-6.

10. Fitzpatrick KE, Sellers S, Spark P, et al. The management and outcomes of placenta accreta, increta, and percreta in the UK: a population-based descriptive study. BJOG 2014; 121: 62-70; discussion 70-71.

11. Eller A, Porter T, Soisson P, Silver R. Optimal management strategies for placenta accreta. BJOG: An International Journal of Obstetrics \& Gynaecology. 2009;116(5):648-654.

12. Berkley E, Abuhamad A. Prenatal diagnosis of placenta accreta: is sonography all we need? Journal of ultrasound in medicine. 2013;32(8):1345-50.

13. Chalubinski KM, Chalubinski S, Pils K, Klein R, Seemann P, Speiser M, et al. Prenatal sonography can predict degree of placental invasion. Ultrasound in obstetrics \& gynecology. 2013;42(5):518-24.

14. D'Antonio F, Iacovella C, Bhide A. Prenatal identification of invasive placentationusing ultrasound: systematic review and metaanalysis. Ultrasound Obstet Gynecol 2013; 42: 509-517.

15. Comstock C, Lee W, Vettraino I, Bronsteen R. The early sonographic appearance of placenta accreta. Journal of ultrasound in medicine. 2003;22(1):19-23.

16. Guleria K1, Gupta B, Agarwal S. Abnormally invasive placenta: changing trends in diagnosis and management. Acta Obstet Gynecol Scand. 2013 Apr;92(4):461-4

17. Warshak C, Ramos G, Eskander R, Benirschke K, Saenz C, Kelly T, et al. Effect of predelivery diagnosis in 99 consecutive cases of placenta accreta. Obstetrics and gynecology. 2010;115(1):65-9.

18. Buetow MP. Sonography of Placenta Percreta During the First Trimester. American Journal of Roentgenology. 2002 2002/08/01;179(2):535.

19. Calì G, Calì L, Giambanco G, Puccio F, Forlani. Morbidly adherent placenta: evaluation of ultrasound diagnostic criteria and differentiation of placenta accreta from percreta. Ultrasound in obstetrics \& gynecology. 2013;41(4):406-12.

20. Garmi G, Salim R. Epidemiology, etiology, diagnosis, and management of placenta accreta. Obstetrics and Gynecology International 2012;2012:1-44.

21. Tikkanen M, Tikkanen J, Paavonen M, Loukovaara V, Stefanovic. Antenatal diagnosis of placenta accreta leads to reduced blood loss. Acta obstetricia et gynecologica Scandinavica. 2011;90(10):1140-

22. Chantraine F, Braun T, Gonser M, et al. Prenatal diagnosis of abnormally invasive placenta reduces maternal peripartum hemorrhage and morbidity. Acta Obstet Gynecol Scand 2013; 92: 439-444.

23. Clausen C, Clausen L, Lönn J, Langhoff R. Management of placenta percreta: a review of published cases. Acta obstetricia et gynecologica Scandinavica. 2014;93(2):138-43.

24. Clausen C, Stensballe J, Albrechtsen CK, Hansen MA, Lonn L, Langhoff-Roos J. Balloon occlusion of the internal iliac arteries in the multidisciplinary management of placenta percreta. Acta Obstetricia et Gynecologica Scandinavica 2013; 92(4):386-91.

25. Wortman A, Alexander J. Placenta accreta, increta, and percreta. Obstetrics and gynecology clinics of North America. 2013;40(1):137-54.

26. Eller A, Eller M, Bennett M. et al. Maternal Morbidity in Cases of Placenta Accreta Managed by a Multidisciplinary Care Team Compared With Standard Obstetric Care. Obstetrics and gynecology. 2011;117(2, Part 1):331-7.

27. Welsh A, Welsh D, Ellwood J, Carter A, Peduto J, Vedelago M, et al. Opinion: Integration of diagnostic and management perspectives for placenta accreta. The Australian and New Zealand journal of obstetrics and gynaecology. 2009;49(6):578-87.

28. Maher M, Maher A, Abdelaziz M, Bazeed. Diagnostic accuracy of ultrasound and MRI in the prenatal diagnosis of placenta accreta. Acta obstetricia et gynecologica Scandinavica. 2013;92(9):1017-22.

29. Esakoff T, Esakoff S, Handler J, Granados A, Caughey. PAMUS: placenta accreta management across the United States. Journal of Maternal - Fetal \& Neonatal Medicine. 2012;25(6):761-5.

30. Eshkoli T, Weintraub A, Sergienko R. Placenta accreta: risk factors, perinatal outcomes, and consequences for subsequent births. Am J Obstet Gynecol. 2013 Mar;208(3):219.

31. Meng X, Meng L, Xie W, Song. Comparing the Diagnostic Value of Ultrasound and Magnetic Resonance Imaging for Placenta Accreta: A Systematic Review and Meta-analysis. Ultrasound in medicine \& biology. 2013;39(11):1958-65.

How to cite this article: Capros Hristiana, Luminita Mihalcean, Iurie Dondiuc, Liliana Porfire. New insights in the diagnosis of placenta accrete. J Clin Med Kaz 2017;4(46):40-45 